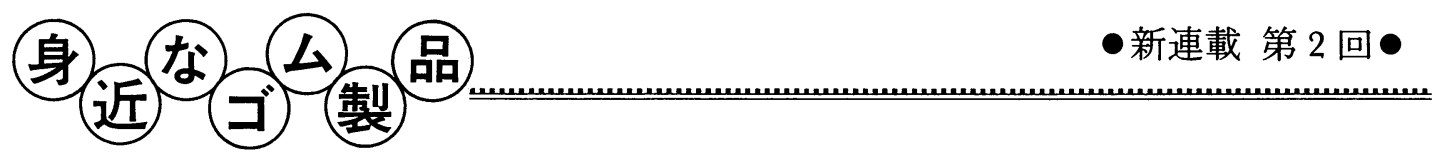

\title{
ゴム製 乳 首
}

高橋＼cjkstart明*

\section{1. は じめに}

生むれて一度はお世話になったことのあるゴム 製乳首は, 多くの衛生上の問題を解決しつつ長い 歴史を経て現在に至っている．原料ゴムは最初天 然ゴムラテックスであったが，その後天然ゴム， イソプレンゴム, シリコーンゴム, 液状シリコー ンゴム (LIMS : Liquid Injection Molding System) と多様化してきた。一方，女性の生活環境の変 化, 近代化, 出生数も昭和24年(1949) 270.5万を ピークとして, 昭和41年 (1966)には136万と低下 し，その後また増加したが，昭和48年(1973)の 209万を最後に低下の一途をたどり，平成 4 年 (1992)121万365人と半減している.

ゴム製乳首は， 1 ケ $5 \mathrm{~g}$ 程度，表面積 $50 \sim 60$ $\mathrm{cm}^{2}$ であるが46,47) お母さん方が最も身近な製品 であるといらことで関心も高く，より良く，使い やすく, 品質, 透明性, 外観, 感触, 形状, 穴の 形，穴の大きさ，そして安全衛生性といら面より 種々の改良が行われてきた。最初はなんといって も透明性が重要なポイントであった。イソプレン ゴムを用いたものでは，透明性，ブルーム，失透 しない見事な配合を作り製品化した 1 9,15 19,23,24). 感触という点については，なんとか理想の乳首を 作りたいと970人の子供を生んだことのある女給 さん(ホステス)の乳房を吸いまくった仕事の鬼 “オッパイ社長奮戦す”と週刊誌 ${ }^{25)} に$ 記載された 販売会社の社長のエピソードがある. 形状につい ても数多くの実用新案が出されているし, 最近教 育テレビでも放映された ${ }^{57)}$. 現在は天然ゴム製は 一部使用されているが，多くはイソプレンゴム， シリコーンゴム製である. 面白いことに天然ゴム
特有のこげ臭いゴム臭が動物，特に豚は非常に好 み，養豚用のゴム製乳首は天然ゴムで作られてい る. 養豚作業者のゴム製長靴に豚がからみつくの と同じ現象である.

また加硫促進剤, 老化防止剂, 促進活性剤がそ の後ゴム製乳首の運命を決するような大きい問題 に発展していくとは誰も予想すらしていなかっ た. 外観, 実用面特に安全衛生面を重要項目とし て, しかもゴム弾性を併せ持ち，100万個単位の 大量生産を行ら製造工程は，医療用ゴム栓製造と 似ているが, 相手が直接乳幼児, 母親である点が ゴム栓の製薬メーカー, 病院, 医者と大いに異な っている. 安全衛生性といら一般のゴム製品と全 く異なる問題を中心として, 歴史的变遷を振り返 ってみる.

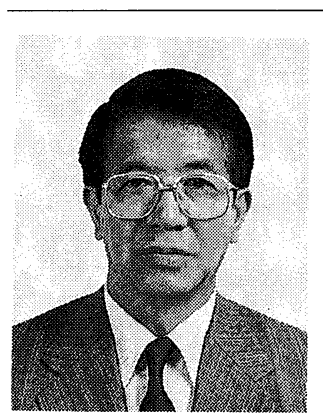

*鈴木ゴム株式会社 ( 131 東京都墨田区東向島 6-38) 顧問. 昭和 22 年, 東京物 理学校(現東京理科大学)理 化卒業. 昭和 22 年, 通産省 工業技術院東京工業試験所 (現物質工学工業技術研究 所) 入所. 昭和 24 年, 昭和 ゴム株式会社入社, 取締役 研究部長, 開発部長を経 て，現在に至る。1985年よ り 2 年 2 か月 JICA ゴム専 門家としてマレーシアクア ラルンプール滞在セランゴ 一, シャーラム, CIAST 勤務.

〈趣味〉テニス, スキー, ゴ ルフ 


\section{2. 衛生 基 準}

ゴム製乳首は我が国の衛生基準の法律として定 められている食品衛生法 ${ }^{28}$ (昭和22年12月 24 日 法律第233号) では厚生省告示第85号 (昭和 61 年 4 月 1 日）「食品, 添加物等の規格基準第 3 器具及 び容器包装の部 D 器具若しくは容器包装又はこ れらの原材料の材料別規格の項 3 ゴム製の器具又 は容器包装」といら大变長い文章に定められてい る. 最初告示第 370 号 (昭和 34 年 2 月 18 日)で「食 品, 添加物等の規格基準合成樹脂の器具または容 器包装」の規格基準が定まり, 次いで告示第 434 号(昭和 41 年10月 4 日) で一部試験法も変わった. その後, 塩化ビニル樹脂をはじめとしてモノマ 一, 樹脂別に規格基準が定められ, 最後に「ゴム 製の器具又は容器包装」が告示第85号で定められ た。この規格にはシリコーンゴム, ウレタンゴム は含まれているが，サーモプラスチックェラスト マーTPEは含まれていない54)。公定書としては 食品衛生検査指針 ${ }^{30)}$, 衛生試験法・注解 ${ }^{29)}$ があ る.これらにはTPE は含まれている。告示第 434 号までは「ほ乳器具は，鉛または亜鉛を含むゴム をもって製造してはならない」，また食品衛生検 査指針+30)(1)には「ほ乳器具のゴム質の検查は鉛と 亜鉛について行う」と検出方法も硝酸カリウムと 炭酸ナトリウムとの同量混和物に試料を加え燃化 し, 少量の硝酸に溶解し, 沃化カリウム飽和溶液 を滴下し黄色の沈澱を生ずれば鉛の反応陽性とし ている. 一方に過鄱のアンモニア水を加え, 煮沸 ろ過し，硫化水素を通じて白色の沈澱を生ずれば 亜鉛の反応陽性（検出限度 $15 \mathrm{ppm}$ ) とし，定量に はキレート滴定法を用いている. 本来は酸化亜鉛 中に存在する金属亜鉛の検出方法と思われるが, 標準的な酸化亜鉛量, 加硫促進剤としてのジチオ カルバミン酸亜鉛類を用いると陽性となる. 告示 第85号, 最新版の食品衛生検査指針, 衛生試験法 ・注解では原子吸光光度法に変わった。諸外国の 例としては，アメリカの FDA ${ }^{31)}$ GFR $21 \S 177$. 2600 「繰返し使用を目的とするゴム製品」ドイッ $\mathrm{BGA}^{32} \mathrm{XX}$ I 「天然合成ゴムをべースとする商品」 があり，B編に乳首の試験 $\mathrm{C}$ 編に乳首中の ロソアミンの定量法が規定されている.

\section{3. ホルムアルデヒド}

昭和44年(1969) 4 月 21 日, 突然東京都衛生局よ
り「合成樹脂製ほ乳びん用乳首」よりホルマリン が検出，食品衛生法に抵触するとし，翌22日メ一 カーは50万個の回収と新聞紙上で大大的に報じた. 23日，メーカー，発売元は抽詫びと回収，交換の 新聞広告を出した。ホルムアルデヒドは少量でも 強い刺激があり，強力な殺菌防腐作用がある，微 量なら今すぐ危険といらわけではないが，長期間 続けて使うと粘膜を刺激し，じん蔵や肝臓にも害 があるとコメントを付け加えた，厚生省環境衛生 局食品衛生課 (現在の生活衛生局食品保健課)は22 日，本件は食品衛生法第 10 条 2 項に違反すると し，ほ乳びん用乳首は厚生省告示第434号の規格 基準を適用するのが正しいとの見解を関係機関に 通達した。ここで初めて食品衛生法といら言葉が 出てきた。第10条は[器具又は容器包装の規格基 準の制定]が定められている.

当時としては，全く何がなんだか雲をつかむよ らでさっぱりわからなかったし，また，なんでゴ ム製品と合成樹脂を一緒にするのか不思議と言う か理解に苦しんだ。告示第434号といら言葉が以 後20年の長い期間，ゴム製品の衛生試験に適用さ れてきた．続いて女子高校生の科学クラブが，ク ラブ活動の一環として, 将来母親となった時使用 する機会が多いゴム製乳首についての分析を行っ た。 ホルムアルデヒドの検出方法は, 食品衛生法 では最初りミニ反応卵白反応からアセチルアセト ン法 (検出限度 $4 \mathrm{ppm}$ ) と変わったが，この公的方 法でない方法を用いて陽性となり，女子高校性の お手柄として，昭和 45 年 (1970) 5 月 14 15日の新 聞紙上をにぎわし，メーカーはその対策，説明に 苦労した。 5 月 17 日, 栃木県環境衛生課は県衛生 研究所の試験結果陰性と発表し決着した. 残念だ ったのはサンプルが昨年問題を起こした回収もれ の古いものであったことと, 女子高校の化学の先 生の知識が狭い分野であったことであった。ホル ムアルデヒド検出の原因は, 加硫促進剤として透 明性ゴムによく用いられるアルデヒドアンモニア 類のへキサメチレンテトラミンである.

\section{4. 過マンガン酸カリウム消費量}

告示第434号がゴム製器具の衛生検査の規格基 準と通達されて以来，ゴム製器具の衛生試験とい えば告示第434号に適合のことと言われるように なり，ゴムに関心を持った衛生研究所，消費者団 体が試験を行い，いくつかの報告がなされた。昭 
和 45 年 (1970) 7 月 29 日, 日本薬学会の年会で, ゴ ム製乳首の過マンガン酸カリウム消費量は9.7 $\mathrm{ppm}$ と規格 $10 \mathrm{ppm}$ ぎりぎりなのでなんらかの規 制が必要であるとの発表があり ${ }^{33)}, 7$ 月30日の新 聞紙上に「野放しゴムの添加剤」と報ぜられた。 日本ゴム工業会は，ゴム検査協会 (現化学品検査 協会) 関西研究所に依頼してゴム製品の実体を告 示第434号にのっとり試験し，8 月 5 日報告書を 受け取った。昭和48年(1973) 3 月 13 日, 神戸生活 科学センターも同様な試験を行い, 追打ちをかけ るよらに新聞紙上をにぎわした. $10 \mathrm{ppm}$ の規格 基準值を充分クリアする製品も加硫促進剤の組み 合わせ, 後処理工程 ${ }^{1)}$,5) 行らことで完成した. 日本のゴム配合技術者は誠に器用であることを見 せつけた．告示第85号では，ゴムに用いられてい る安定剤, 老化防止剂によることが判明している ので，合成樹脂と同一に扱うのは無理との理由で 削除された。

\section{5. 亜鉛}

ゴム製乳首にますます関心が高まり，大学，衛 生研究所 ${ }^{34)}$, 消費者団体が, 食品衛生法, 食品衛 生検查指針, 衛生試験法・注解を精読するように なり，これらに記載されている「浮孚具は鉛ま たは亜鉛を含むゴムをもって製造してはならな い」の亜鉛を取りあげるようになった．昭和 48 年 12月 4 日，亜鉛の多量溶出で九州地区で立入検査 があり, 昭和55年 (1980) 4 月 1 日広島県消費生活 センターニュースで報告され，4月19日同センタ 一の発表が新聞紙上に記載された。一部のスーパ 一では商品を陳列棚より外す動きが出た。昭和 49 年(1974) 5 月 9 日, 島根県衛生公害研究所が細胞 培養による毒性試験 ${ }^{35)}$ でコロニー阻止の報告につ いて新聞で報ぜられた。昭和48年 1 月 20 日，日本 ゴム工業会, 日本ゴム協会，ゴム工業技術員会 (現研究部会)が連名で日本薬学会衛生化学調査委 員会に亜鉛の問題に関して意見書と現状について の資料をそえて提出した，幸いなことに，日本薬 学会では, 現状の矛盾とゴムに興味を持って下さ る委員の方が多く、器具等部会で取りあげると し, 同時に昭和49年 4 月より私も委員に任命され 平成 3 年 (1991) までの 17 年間にわたって委員を務 めた。部会の委員先生方のゴム工場見学会も行 い，認識を新たにしていただいた。日本ゴム協会 技術員会衛生特別委員会 (現技術部会衛生問題研
究分科会)の委員の協力を得て, 日本薬学会衛生 化学 ${ }^{36)}$ に「ゴム製器具」の項目が新設記載され, 衛生試験法·注解1980年版に独立記載され, 1990 年版で一部改正した。不充分の個所もあり, 目下 修正案を作成中である. 告示第85号で带鉛の溶出 量 $1 \mathrm{ppm}$ 水道水の規格基準值と同一に決まり, 一件落着した.

\section{6. ジブチルヒドロキシトルエン BHT}

昭和52年 (1977) 11月 30 日,「プラスチック食器 の安全性について」のテーマで関西消費者団体連 絡懇談会の対話集会が大阪市で開催され, 大阪大 学の植村振作氏がプラスチック,ゴムの安定剂, 老化防止剂として用いられている BHT の安全性 およびゴム製乳首中の BHT 量, ミルクへの溶出 量について発表し, その夜関西ではテレビの二ュ 一ス番組で放映された。発がん性問題でサッカリ ンの黒白が途中で変わったりして，はっきりして いなかったのを受けて，またしても大きい問題と なった. IR 中には $0.15 \%$ 程度安定剂として添加 されているが，ゴム製乳首に用いる IR は使用量 を最少限度とし $0.1 \%$ 以下としている．日本ゴム 工業会食品医療用品連絡会はこの問題について昭 和52年12月 12 日ゴム, 医療関係新聞の記者会見を し, 安全性について新聞発表を行った. 続いて昭 和53年(1978) 6 月 6 日, 追い打ちをかけるように 「衆議員公害対策並びに環境保全特別委員会」に おいて社会党の土井たか子女史(現衆議院議長元 社会党委員長)が BHT の安全性损よび厚生省の 対応について質問を行った。このとき初めて精力 的な土井たか子女史の名を知った。 そしてどこか 一般の議員とは異なっている印象を受けた。昭和 53 年 (1978) 7 月22日, 関西消費者団体連絡懇談会 より日本ゴム工業会長宛「ほ乳びんの乳首に関す る要望書」が提出された。 プラスチックを中心と して, BHT の安全性, 対策については長い間論 議が行われ, ミルクへの溶出に関する報告書も出 ている ${ }^{37)}$. BHT の安全性問題は昭和52年 6 月 20 日東京都立衛生研究所の「ポリプロピレン問題調 查委員会」の白といら報告で終止符が打たれ， 7 月14日の新聞でも報ぜられた。

$$
\text { 7. ニトロソアミン }
$$

昭和 56 年 (1981) 1 月 29 30日の新聞で，スイス 連邦保健局はオランダが輸入したゴム製乳首，お 
しゃぶりより $10 \sim 100 \mathrm{ppb}$ の $\mathrm{N}-$ ニトッフミン を検出, その中に日本より輸出されたものも含ん でいると報道した，ppbといら今までにない，あ まりゴムに縁のない微量なので,一体どらいらこ とか, どのような測定をすればよいのか，またこ のような微量の製品は製造可能かについて，どう やって手をつけていったらよいか見当がつかなか った。昭和 56 年 9 月 28 日〜 10月 1 日, 東京に颃い て開催された第 7 回国際ニトロソ化合物研究会議 で German Cancer Research Center の Prof. Dr. Preusmann R., Dr. Spiegelhalder B., により 「Nitrosamines and Rubber」といらテーマでほ乳 びん用ゴム製乳首，おしゃぶり中の $\mathrm{N}-$ ニトロソ アミンおよびニトロソ化可能物質についての発表 があった ${ }^{40)}$. 最も恐れられているガンという問題 なので一大センセーションを巻き起した. この発 表の中にシリコーンゴム製乳首からもわずかなが ら $\mathrm{N}-$ ニトッアミンが検出されているデータが あり, 不思議な感を持った. シリコーンゴムメー カーは昭和56年 9 月, 12 月と 2 回国内の衛生研究 所, 分析センターで分析を行い不検出を確認し た. しかし，シリコーンゴムは長期間一般のゴム と一緒に置いておくと, 空気中に浮遊している加 硫促進剤が吸着されるとか, 移行現象のあること が後でわかった. 研究発表時, 両博士とのミーテ ィングを持つことができ種々の細かい情報を得る ことができた。11月，発売元大手 2 社が「使用の お客様ご安心下さい」のチラシ配布, 11月26日加 硫促進剂等について 3 点の規制要求の要望書を厚 生大臣宛日本消費者協会が提出した。また11月27 日, 厚生省食品衛生課長談話として56年 4 月ゴム 製器具研究班発足, 現状のゴム製乳首中の 10 $\mathrm{ppb}$ 以下と聞いているニトロソアミンに加えて 2 級アミンの規制も行うと発表した. 12月 4 日消費 者新聞に哺乳ビンにまたも有害物質, 強力発ガン 性有するニトロソアミン問題が浮上, 大手独占入 ーカーのピジョンも黒. 12月14日強い発ガン性物 質(ニトロソアミン)哺乳ビンの乳首に含有, 厚生 省へ対策を要望. 昭和57年 (1982) 月刊『消費者』 2 月号に乳首から発ガン物質検出，ニトロソアミ ンとその前駆物質, 3 月27～28日東京都地域消費 者団体連絡会主催の「第 8 回消費者から見た欠陥 商品展」, 5 月 1 日消費之生活社発行の消費と生 活125号. 11月17日赤旗日曜版にゴム製乳首から 発ガン物質, 天然ゴム, イソプレンゴム製品に多
量, 厚生省も規制づくりへ.12月15日ニッポン消 費者新聞にゴム製乳首やはり軒並久黒, 都衛研調 查でも多量の発ガン物質・ ニトロソアミン検出. 12月 17 日日本消費者連盟, 消費者レポート第 488 号にゴム製乳首とだ液が反応発ガン物質が。また 諸外国でも新聞紙上で話題となった ${ }^{50)}$. 発ガン性 のない $\mathrm{N}-$ ニロソアミンを生成する二級アミン の加硫促進剂を用いるか又は全く $\mathrm{N}-$ ニトッフ ミンを生成しない加硫促進剂を用いて，透明性で ブルーム，失透しない感触のよいゴム製乳首の製 造は可能かについて関係各社の技術者は研究に取 り組んだ。幸いHeiderberg の German Canser Research Center 3 回, Leverkussen $の$ Bayer $へ 2$ 回, Amsterdam の Shell 1 回出張する機会に恵 まれ, 多くの学者, 技術者と $\mathrm{N}-$ ニロソアミン 問題について討論することができた．その後 Nニトロソアミンについては多くの10〜14,20〜22)特許, 報告が出された ${ }^{26,27,38 \sim 52)}$. 放射線照射による Nニトロソアミンを生じない方法も開発されたと聞 いている．業界が力を合わせて対策に取り組み， 現状は $10 \mathrm{ppb}$ をりリーする製品も完成してい る. 検出器の GC-TEA (ガスクロマトグラフ熱エ ネルギー検出装置) も現在は多くの衛生研究所, 分析センターがそろ光, 検出方法, 前処理, 分析 上の問題点についても検討がなされている56)が, この問題は今後長びく傾向がある. また食品衛生 検查指針, 衛生試験法・注解に注釈が記載されて

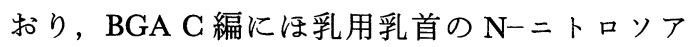
ミンの分析法が記載されている.

\section{8. その他の問題}

問題点として取りあげられなかったが，老化防 止剂のモノフェノール類のスチレン化フェノール のように告示第370号の臭素法, 告示第434号, 第 85号の 4-アミノアンチピリン法でも陽性を示す ものがあり, フェノール類の老化防止剤の使用に 当たっては量とともに注意する必要がある．シリ コーンゴムの架橋剤として用いる2,4-ジクロロベ ンゾイルペルオキシドは分解して2,4-ジクロロ安 息香酸が残留し, 抵抗力の弱い乳幼児であること から毒性問題の検討が必要との報告 ${ }^{53)}$ が出され た. 現在は分解してアルコールの形となる安全性 の高いジアルキルペルオキシド類が用いられてい る、また細胞培養による毒性試験 ${ }^{35)}$ でコロニー形 成阻止, 有害なシリューンゴム乳首として昭和 49 
年(1974) 5 月 9 日新聞紙上で問題となった。しま いには昭和 53 年 (1978) 2 月 22 日の新聞にゴム製乳 首よりフタル酸エステル検出の記事が出るほど関 心の深さをらかがわせた. 不純物の多い 3 号酸化 亜鉛を用いると鉛，亜鉛陽性となるので注意する 必要がある.

\section{9. 厚生省告示第85号}

厚生省告示第85号は，昭和61年(1986) 4 月 1 日 制定された「ゴム製の器具又は容器包装」の規格 基準である.「ゴム製の器具( ほ乳器具を除く) 又 は容器包装」と「ゴム製ほ乳器具」よりなってい る. 明治33年 (1900)「飲食物用器具取締規則」に より「営業者は哺乳器具を鉛又は亜鉛を含むゴム をもって製造することを得ず」とされ，ほぼその まま, 今回の改正に至るまで「浮乳器具は, 鉛又 は带鉛を含むゴムをもって製造してはならない」 として規制されていた。一方，合成樹脂の原材料 別の個別規格が順次整備されていった. ゴムの特 徵はなんといってもゴム弾性であり, 使用実体と してゴムが器具又は容器包装の一部として使用さ れている. 食品に直接接触することは少ないゴム 製乳首の場合，表面積は50〜 $60 \mathrm{~cm}^{2}$ である ${ }^{54,55)}$.

\section{1）材質試験}

a. カドミウムおよび鉛 合成樹脂では 100 ppm であるが乳幼児が直接口に含むものであ ることなどを勘案して $10 \mathrm{ppm}$ とした。

\section{2）溶出試験}

ゴム製乳首の表面積は50〜 $60 \mathrm{~cm}^{2}$ 重量 $5 \mathrm{~g}$ ぐら いであるが，表面積の測定が困難であることから 重量 $1 \mathrm{~g}$ につき $20 \mathrm{ml}$ の指定された浸出溶液を用 い, $40^{\circ} \mathrm{C}$ で24時間浸出することにより試験溶液 を調製する。これは，ゴム製乳首の使用実態を勘
案したものである。

a.フェノール 4-アミノアンチピリンを用 いての吸光度測定, モノフェノール類のスチレ ン化フェノールのようなものを使用すると陽 性, 検出限度 $5 \mathrm{ppm}$.

b. ホルムアルデヒド アセチルアセトン法, 透明ゴムによく用いられるアルデヒドアンモニ ア類のへキサメチレンテトラミンを使用すると 陽性, 検出限度 $4 \mathrm{ppm}$. 感度がよく微量も検出 できる4-アミノ-3-ヒドラジノー5ーメルカプトー 1,2,4-トリアゾール (AHMT) も用いられる.

c. 亜 鉛 原子吸光光度法 $1 \mathrm{ppm}$ 水道水の 規格基準值と同一，BGA では $1 \%$ 以下. 酸化 亜鉛の使用量は一般のゴム配合より極端に少な くする必要がある.

d. 重金属 浸出溶液として $4 \%$ 酢酸を用い る. 硫化ナトリウム法, 鉛として $1 \mathrm{ppm}, 3$ 号 酸化亜鉛を用いると最大 $0.3 \%$ の鉛が含まれて いるので注意する必要がある.

e. 蒸発残留物 食品に移行する不揮発化学 物質を検出するのが目的である、ゴムは加硫促 進剤, 加硫促進活性剂等を用いるので合成樹脂 の30 ppm より大きい $40 \mathrm{ppm}$ とした。

過マンガン酸カリウム消費量についての原因 は，天然ゴムに含まれているタンパク質，加硫促 進剤, 安定剂, 老化防止剂によるといらことが判 明しているので，どうしても合成樹脂のように小 さい値とならないので除外した。

10. 配合, 製造方法

\section{1 天然ゴムラテックス（NRラテック} ス) ${ }^{9,24)}$

前加硫 $60^{\circ} \mathrm{C}$ で $1 \sim 2$ 時間, $70^{\circ} \mathrm{C} て ゙ 60$ 分間乾燥,

\begin{tabular}{|c|c|c|}
\hline & 凝着浸せき法 & 感熱浸せき法 \\
\hline $60 \% \mathrm{NR}$ ラテックス $\mathrm{LA}^{* 1}-\mathrm{TZ}^{* 2}$ タイプ & 167 & 167 \\
\hline 70\%ラウリン酸カリウム & 2 & - \\
\hline 10\%水酸化カリウム & 2 & - \\
\hline 20\%非イオン界面活性剤 & - & 2 \\
\hline $40 \%$ ホルムアルデヒド & - & PH $7.5 \sim 8.0$ \\
\hline $50 \% \mathrm{ZnBDC}^{* 3}$ & 2 & 2 \\
\hline $50 \%$ 硫黄 & 2 & 2 \\
\hline $10 \%$ ポリビニルメチルェーテル & - & 10 \\
\hline
\end{tabular}

$*_{1}$ LA : 低アンモニアタイプ

*2 $\mathrm{TZ}$ : 二次保存剤として TMTD, 酸化亜鉛を用いたもの

*3 ZnBDC : ジーnーブチルジチオカルバミン酸亜鉛 
$60 \sim 65^{\circ} \mathrm{C}$ で 3 時間リーチングによりタンパク質, 性保持, 耐吸湿性のため, クロリネーション*を 水性成分を除去, $70 \sim 75^{\circ} \mathrm{C} て ゙ 15$ 時間乾燥, 透明行い, 水洗, 乾燥する.

10.2 天然ゴム(NR) ${ }^{23), 24)}$

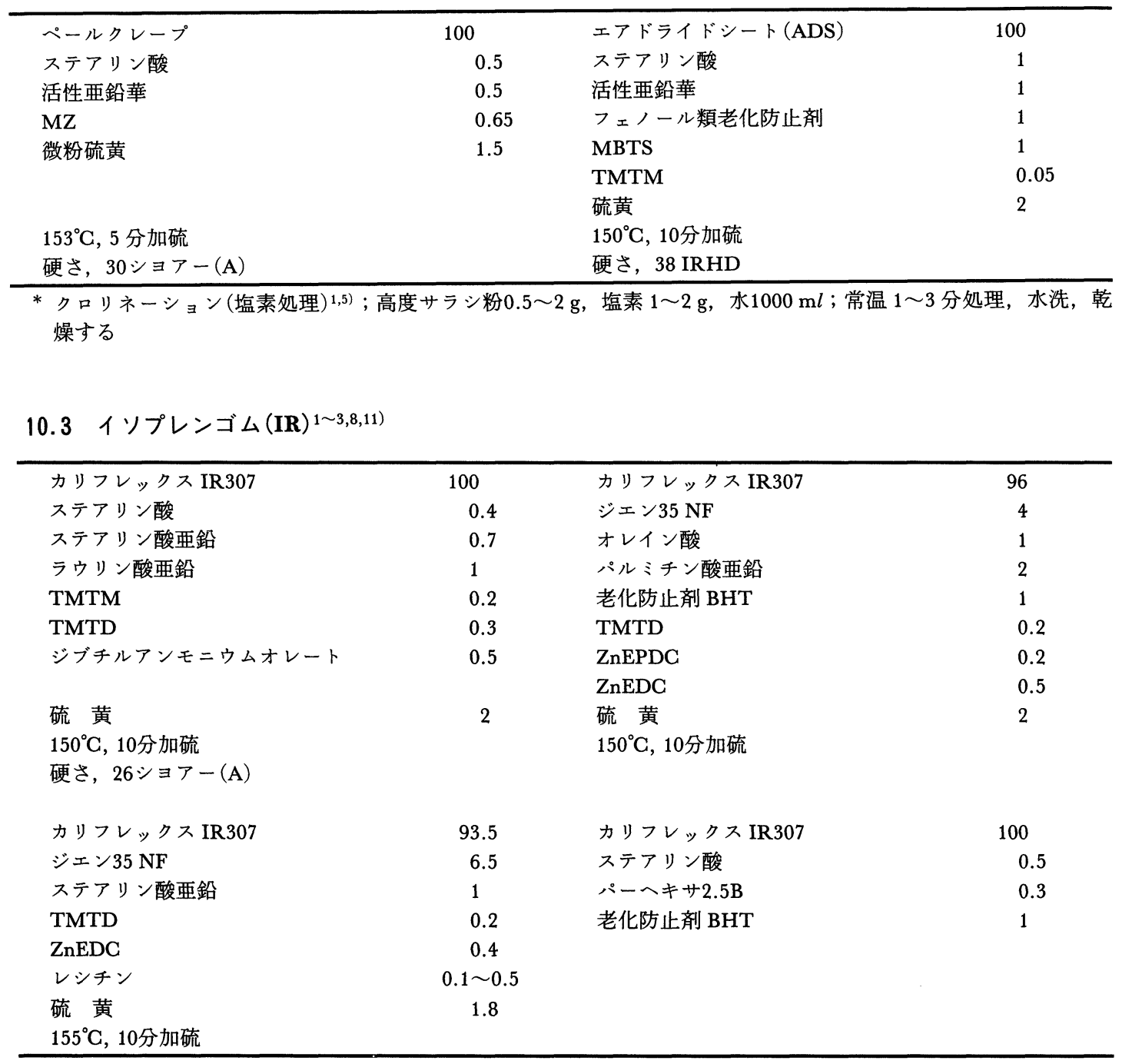


10.4 イソプレンゴム(IR)を用いた $\mathbf{N}-$ ニトロソアミン対策 ${ }^{10 ~ 22)}$

\begin{tabular}{|c|c|c|c|}
\hline カリフレックス IR307 & 75 & カリフレックス IR307 & 100 \\
\hline ジェン $35 \mathrm{NF}$ & 15 & ジェン $35 \mathrm{NF}$ & 7 \\
\hline $\mathrm{NR}($ ペールクレープ IX) & 10 & ステアリン酸亜鉛 & 1 \\
\hline ステアリン酸亜鉛 & 1 & TMTD & 0.2 \\
\hline 活性亜鉛華 & 0.2 & ZnEDC & 0.44 \\
\hline DPTT & 0.5 & レシチン & $0.1 \sim 0.5$ \\
\hline $\mathrm{ZnBDC}$ & 0.3 & トコフェロール & 1 \\
\hline ZnEDC & 0.1 & $\begin{array}{l}\text { 硫黄 } \\
155^{\circ} \mathrm{C}, 10 \text { 分加硫 }\end{array}$ & 1.9 \\
\hline L-アスコルビン酸 & 0.05 & & \\
\hline $\begin{array}{l}\text { 硫黄 } \\
150^{\circ} \mathrm{C}, 8 \text { 分 }\end{array}$ & 1.5 & & \\
\hline カリフレックス IR307 & 100 & & \\
\hline ラウリン酸亜鉛 & 0.5 & & \\
\hline TMTD & $0.01 \sim 0.05$ & & \\
\hline ZnMDC & $0.03 \sim 0.05$ & & \\
\hline ジベンジルジチオカルバミン酸亜鉛 & 0.2 & & \\
\hline トコフェロール & $0.2 \sim 1$ & & \\
\hline $\begin{array}{l}\text { 硫黄 } \\
150^{\circ} \mathrm{C}, 10 \text { 分加硫 }\end{array}$ & 1.5 & & \\
\hline
\end{tabular}

\section{5 シリコーンゴム}

ミラブルタイプとしては，ビニル系の高引裂， 透明性の良い無味, 無臭, 無毒のものが用いら れ, 架橋剤としては, 分解してアルコールとなる ジアルキルペルオキシド類のジーt-ブチルペルオ

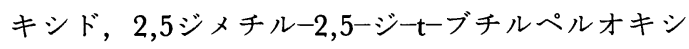
へキサンを用い $170^{\circ} \mathrm{C}, 10$ 分程度の一次加硫後, $200^{\circ} \mathrm{C} ， 4$ 時間の二次加硫を充分行う。最近は液 状シリューンゴム射出成形システム (LIMS)が採 用され，二液性の白金触媒の付加反応型を用い， $120^{\circ} \mathrm{C}, 5$ 分の一次加硫, $150^{\circ} \mathrm{C}, 1$ 時間程度の二次 加硫を行う. 成形工程を機械的に一元化したクロ ーズドシステムなので, 成形品に異物の混入が少 ないので今後ますます伸びることが考えられる.

\section{1. まと め}

我々は使用目的に適した特性を持ち，消費者の 求めているゴム製品を作ることに目標が向けられ ている、ゴム製乳首は最初天然ゴムラテックス， 天然ゴムが中心であったが，合成ゴムの生産開始 にともなってIRを用いて製造し，そしてシリコ ーンゴム製も加わった. 原料ゴム以外の架橋剤, 加硫促進剤, 加硫促進助剂, 老化防止剂, また溶 出物, 溶出量について次から次と安全衛生上の大
きい問題を抱え，ゴム製品の衛生問題を全部ゴム 製乳首がかぶってしまったが，ひとつひとつ慎重 に取り組み，勉強しつつ解決していった，当時食 品衛生法はゴムについて確立していなく，合成樹 脂中に包合され考えられていた，厚生省といら分 野も馴みがなかったし，公定の検査方法はどらな っているのか, どこに記載されているのか，どう 解釈したらよいのか大変苦労した. 一方, ゴム工 業全体から見ても食品関係のゴム製品は医療用ゴ ム製品より少なくメーカーも限定されている．昭 和51年 (1976) 9 月 16 日日本ゴム工業会食品医療用 品連絡会が発足し, 昭和53年 (1978) 5 月 9 日部 会となり，ひとつの空口ができ対外接渉も楽にな ったのは幸いである。日本薬学会衛生化学調査委 員会器具第部会 (現試験法委員会器具・玩具試験 法小委員会)がゴムを取り上げて下され, 衛生試 験法・注解1980年版に初めて「ゴム製器具」の項 目が独立した。これを契機として告示第85号, 食 品衛生検查指針理化学編が制定された. 思えば大 変長い期間を要したものである. 告示第 85 号では TPE は含まれていないが, 衛生試験法・注解, 食品衛生検查指針理化学編は含まれている. BGA のようにウレタンゴム, LIMS のシリコー ンゴムも多くなりつつあるので, シリコーンゴム 
を別々に独立規格とする必要があるのか，そして 今後利用されることが考えられる TPEの取扱い は今後の問題である，そしてな誌続いている Nニトロソアミン問題は今後とも尾を引くことが考 亲っれる。

〔追記】育児用品特にゴム製乳首に情熱をそそが れたオッパイ社長，ピジョン侏仲田祐一会長が平 成 5 年 9 月 21 日死去された。 この記事が完成する 途中であった。心から哀悼の意を表したい。

\section{文献}

1）合成ゴム技術“カリフレックス” IR307，NO. TB203, 12〜14 (1979), シェル化学

2）日特公昭47-22, 095 特許 No. 700, 240

3） 日特開昭 $52-78,694$

4） 日公開昭52-110,167

5）日特公昭53-1300 特許 No. 924, 115

6）日特公昭53-13,383

7）日特公昭53-13, 384 特許 No. 933, 484

8）日特公昭53-16, 409 特許 No. 937, 634

9） 日特公昭55-2190

10） 日特開昭57-212, 243

11）独特 : $3029318 \cdot 6$ (1981)

12）日特開昭58-2, 337

13） 日特開昭 58-5, 349

14） 日特開昭 $58-5,350$

15）日特公平 1-19, 414 特許 No. 1, 537, 194

16）日特公平 1-20,650 特許 No. 1, 537, 188

17）日特公平 1-30, 499

18）日特公平 1-34, 458

19）日特公平 1-50, 253

20）日特開平 3-276, 118

21） 日特開平 4-249, 555

22）日特開平 4-266, 946

23）妻鹿菊夫：妻鹿技術事務所 (1987)

24) The Natural Rubber Formulary and Property Index MRPRA (1984)

25）週間文春，37，2，5号（1962），日本工業新聞，51， 11月 8 日号 (1979)

26) トピックス:ポリファイル，4,25 (1984)

27）小林幸夫：ポリマーダイジェスト，10,42（1993）

28）食品衛生法, 食品添加物等の規格基準, 厚生省告 示第370号 (昭34年12月28日), 第434号(昭41年10月 14 日) 第 85 号 (昭61年 4 月 1 日)

29）衛生試験法·注解 日本薬学会, 金原出版(1980), P. 581，(1990) P. 746

30）食品衛生検査指針 I 検査法別, 協同医書出版 （1956）P. 14, 再版日本食品衛生協会, 理化学編, 日本食品衛生協会 (1991) P. 585

31) CFR 21, FDA, Subpart $C \S 177.2600$ Rubber articles intended for repeated use

32) Kunststoffe im Lebensmittelverkehr Empfehlungen des Bundesgesundheitsamtes BGA B XXI Bedarfsgegenstände auf Basis von Natur-und Synthese kautschuk, C Bestim- mung von Nitrosaminen in Bestimmten Bedarfsgegenständen (Babysauger)

33）馬場二夫, 楠本一枝, 水谷泰久：日本薬学会 90 年 総会(1970); 大阪市衛研報告, 第33集135 (1970); 馬場二夫, 楠本一枝, 山田正二：日本食品衛生学会 第32回学術講演, 51 (1976)

34）西田茂一, 小林史尚：都衛研年報, 24, 167 (1972)

35）板垣朝夫, 犬山義晴, 河原富美子, 米田孟弘：日 本食品衛生学会第27回学術講演会, 30 (1974)

36) 衛生化学, 日本薬学会, 22, 3, 128 (1976)

37）福井弥生, 馬場二夫, 斉藤稕, 大宮季宏, 谷田 繁：日本食衛誌，21，1，37（1980）, 日本食品衛生学 会第35回学術講演会 (1978)

38）馬場二夫, 斉藤整, 福井弥生, 谷口繁, 大和田国 夫，水谷泰久：日本食衛誌， 19, $530(1978)$

39）馬場二夫, 大宮季宏, 細川学, 斉藤穰, 福井弥生, 石橋武二：大阪環境研報告調査・研究年報，45, 106 (1982), 日本食品衛生学会第43回学術講演会 (1982)

40) Spiegelhalder, B., Preusmann, R.: 7th International meeting on Analysis and Formation of N-Nitroso Compounds (1981)

41）馬場二夫, 斉藤穰, 福井弥生, 谷口繁, 水谷泰 久：日本食衛誌，21，32（1980）

42) 石綿肇, 川崎洋子, 山本都, 酒井綾子, 山田隆, 谷村顕雄 : 衛試報告, 99, 135 (1981)

43）辰濃隆, 山田隆, 井上たき子, 谷村顕雄 : 衛試報 告100, 62 (1982)；100, 68 (1982)；第18回全国衛生化 学技術協議会 (1981)

44) 水石和子, 竹内正博, 吉原武俊 : 東京都衛生局学 会誌，69，(1982）

45）国守利, 中嶋陽一, 中西弘, 武田義雄 : 食品衛生 研究, 36, 7, 39 (1986)

46) 谷村顕雄：月刊消費者, P. 363 (1983)

47) Havery, D. C., Fazio T.: Fd. chem. Toxic.: 22, 939 (1982)

48) Fazio, T., Havery, D. G.: IRAC Scientific Publications, No. 41, 277 (1982)

49) Sen, N. P., Seaman, S., Clarkson, S., Garrod, S., Lalonde, P.: 出所不明

50) Utusan Malaysia: Putting Susa Dari Getah Asli Lebih Sekmat Dari Silikon (Test from natural rubber is more Safer than Silicon rubber) 1987. 1. 13., Get the facts for your baby's benefits: New straits times malaysia 1986. 11. 8

51) Hofmann, W.: ポリマーダイジェスト， 1, 65 (1991), 131 （1991)訳

52）沖倉元治：ポリマーダイジェスト，12，93（1987） 1, 95 (1988), 3, 91 (1988)

53）馬場二夫，楠本一枝，水谷泰久：大阪市衛研報告, 第34集, 161 (1971), 第22回日本食品衛生学会学術 講演会 $(1971)$

54）成田昌稔：食品衛生研究，36, No. 77 (1983)

55）辰濃隆：食品衛生研究，36, No. 725 (1983)

56）長谷川潤一, 石橋亨, 松居正巳 : 第 2 回環境化学 討論会 (1993)

57） NHK TV3 1993．5.13放映，身近なゴム製品シリ 一ズ乳首すくすく赤ちゃん育児グッズのそこが知り たいほ乳用乳首 